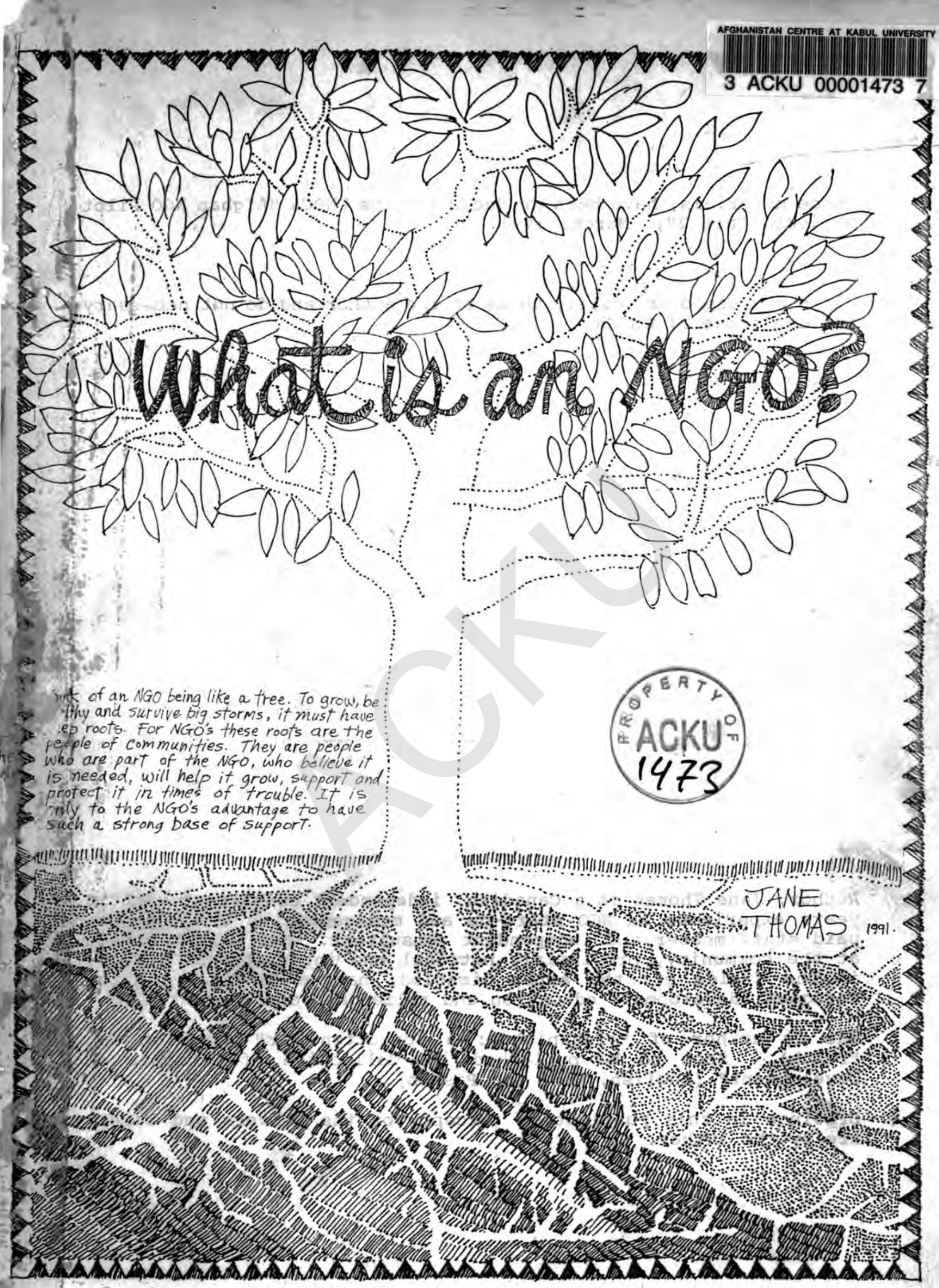


These materials, have been produced for the UNOCA "Afghan NGO Pilot Project, Part 2", March, 1991.

Views expressed are solely those of the author and do not necessary reflect those of UNOCA.

Author, Jane Thomas is a Canadian, independent consultant with 20 years experience in NGO start-up and management as a volunteer, paid staff member and independent consultant. Her work has been at the community, provincial, national and international levels, in the fields of; the arts, disabled, native Canadian rights, refugees, development education and relief and development.

She is author of "Afghanistan: a Forgotten War" (English and French). Soon to be published, "A Collection of Thoughts on Development" (English, Dari and Pashto).

Drawings in this publication (except for the flowers and birds) are by the author. 
Summary: What is an NGO?

A. KINDS OF NGOS

By Reasons to Exist (Objectives)

-to support, encourage, promote, protect, etc...

-religion

-social work

-education

-recreation \& sports

-the arts

-business

- peace \& justice

-human rights

-relief and development

-professional development

-health

-environment

-etc.

\section{By Scope}

-community (comprised mainly of people of a community)

-regional (is a community of communities)

-provincial (is a community of the regions)

-national (is a community of the provinces)

-international (is a community of at least two countries)

B. What is an NGO?

-voluntary

-not-for-profit

-accountable

To be the above, an NGO needs:

-a strong base of support; a community

-a structure made up of:-an active, volunteer, elected leadership

-members (to elect leadership, etc.)

-a set of rules (constitution)

-volunteers, contributors, community participation and

representation.

- a humanitarian NGO needs clear ideas of humanitarianism

-a relief and development NGO needs clear ideas about relief and development

-good management. What is management? Plan, Control, Evaluate. 


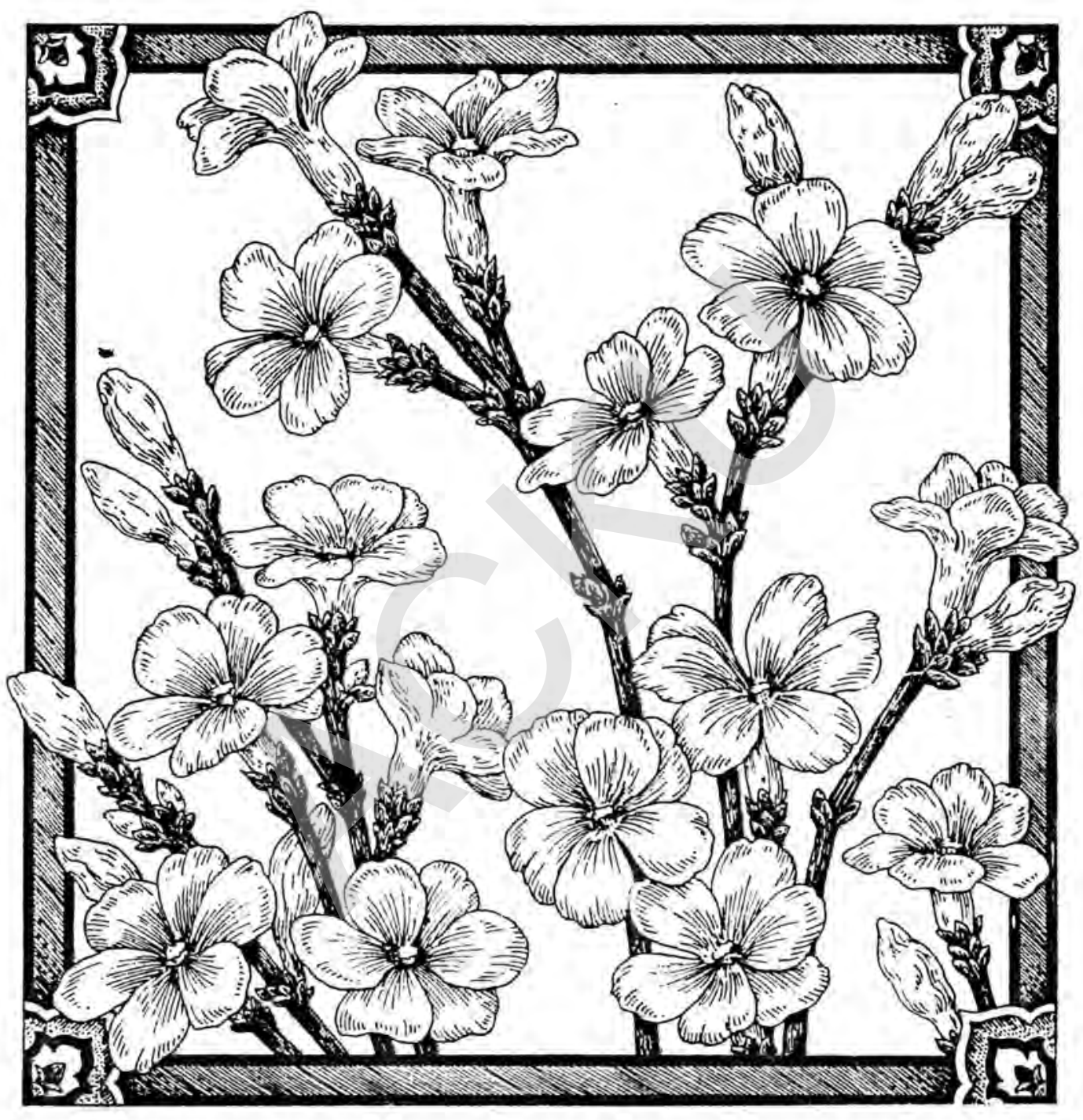




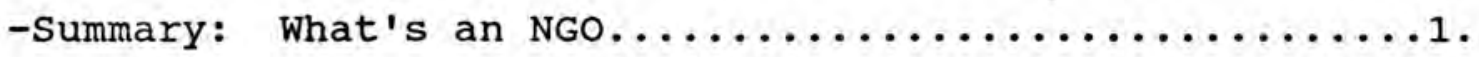

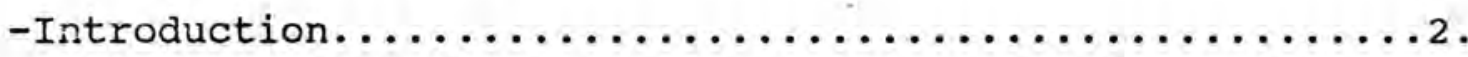

-Kinds of NGOs: A Trip to a Food store................

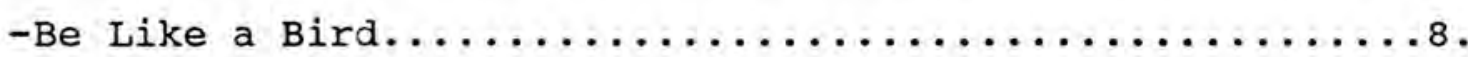

-History of NGOs: The Old Way is the New Way...........

-Difference Between Traditional organizing and an NGO...12.

-Learning from Afghan carpet makers (drawing) .......... 15 .

-An NGO is like a tree and its's roots (drawing) .........

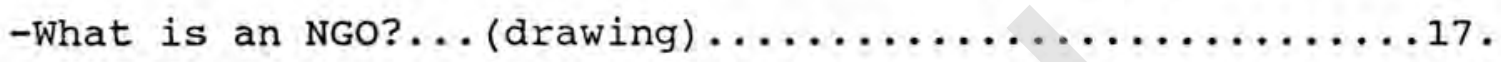

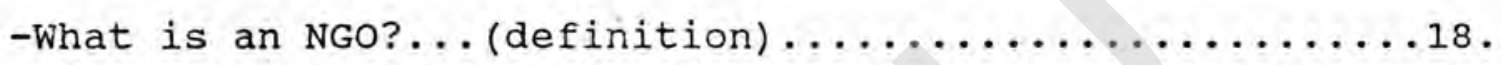

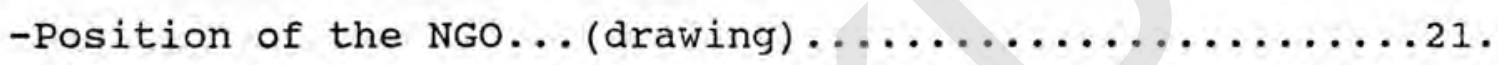

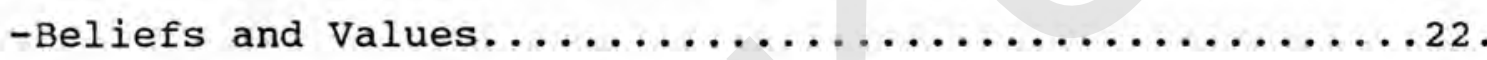

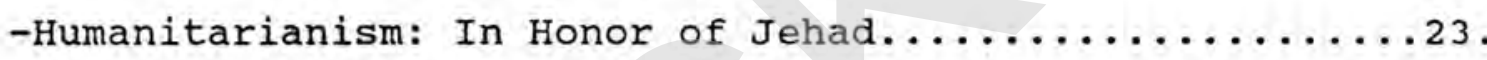

-Give a man a fish..... (drawing) ..................

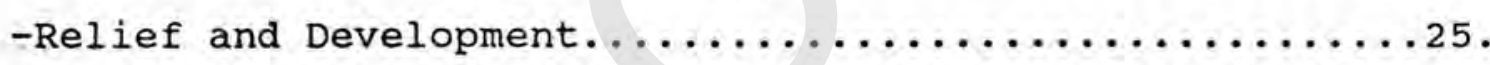

-NGO Organizing and Fundraising wheel..............

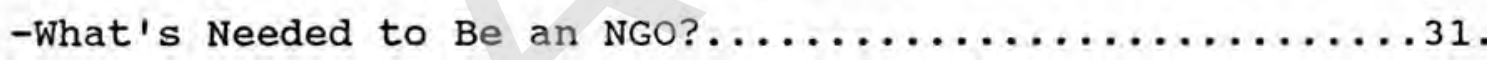

-Questionaire for Afghan NGos..................

Note:

A) In this writing, Canada is mentioned a number of times only because the author is Canadian and it is the country she knows best. It is not in any way to promote Canada: only use it as a contrast and comparison to Afghanistan and it's NGOs. Canada is believed to have the highest per capita number of NGOs in the world ( 100,000 in a population of 25 million), but they have similiar problems to NGOs everwhere. Almost every other country has NGOs and there is very much to learn from all.

B) This author uses the words, countries of the "North" and "South" instead of the more common "developed" and "developing" "rich" and "poor", "First world" and "third world". 
In early 1991, there are at least 44 Afghan NGOs located in Peshawar, Islamabad and Quetta and most are less than two years old. If one good thing has come of the war in Afghanistan it is that Afghans have formed their own humanitarian agencies to rebuild and develop their country.

There is no history of Afghan NGOs: before the war they didn't exist. The only examples Afghans have had are the foreign NGos also based in Peshawar, Islamabad and Quetta. From these, Afghans have "learned", what an NGO is. The trouble is, that only a part of the foreign NGO is here. The part most important to understanding what makes an NGO an NGO is overseas, and of course invisible to us in Peshawar.

\section{All NGOs everywhere have two parts:}

1-the central organizing or internal part

2-the "external" part; the activities, programs or projects which can be seen in the public

In Peshawar, only the projects part of the foreign NGO can be seen. The central organizing or internal part -the core of the NGO- is on the other side of the world, in places like London, Paris, New York, Oslo or Hamburg. In those cities, Afghans would see what makes an NGO and NGO: high numbers of volunteers, a base of support (people who contribute and help in many ways), and the NGO being accountable to that community, their own governments and so on. In this case, "community" could be thought of as the people in the foreign country who are interested in helping Afghanistan. It appears that foreign NGOs do not consider themselves accountable to Afghans.

Generally, in the home countries, the foreign NGOs keep costs very low. For example; in sweden the swedish committee has 4,000 members in 30 towns, a Board of directors of 25 and the head office is staffed by only three people. In Peshawar they are the largest cross-border NGO. Afghanaid from England has four paid staff people in their London head office and their volunteers consist of the Board of Directors. Human Concern International from Canada has two full time paid staff in their ottawa head office, a Board of Directors, 18 official representatives in 18 cities and 250 volunteers.

A lot can be learned by studying foreign NGos, even if its two parts are separated but it is this separation that makes it so unlike other kinds of NGOs. International relief agencies are not at all typical of what NGOs are. Only a tiny fraction of the world's NGOs work away from their own countries. For example, out of Canada's 100,000 NGOs, only 400 (or .04\%) work in other countries in "relief and development". 


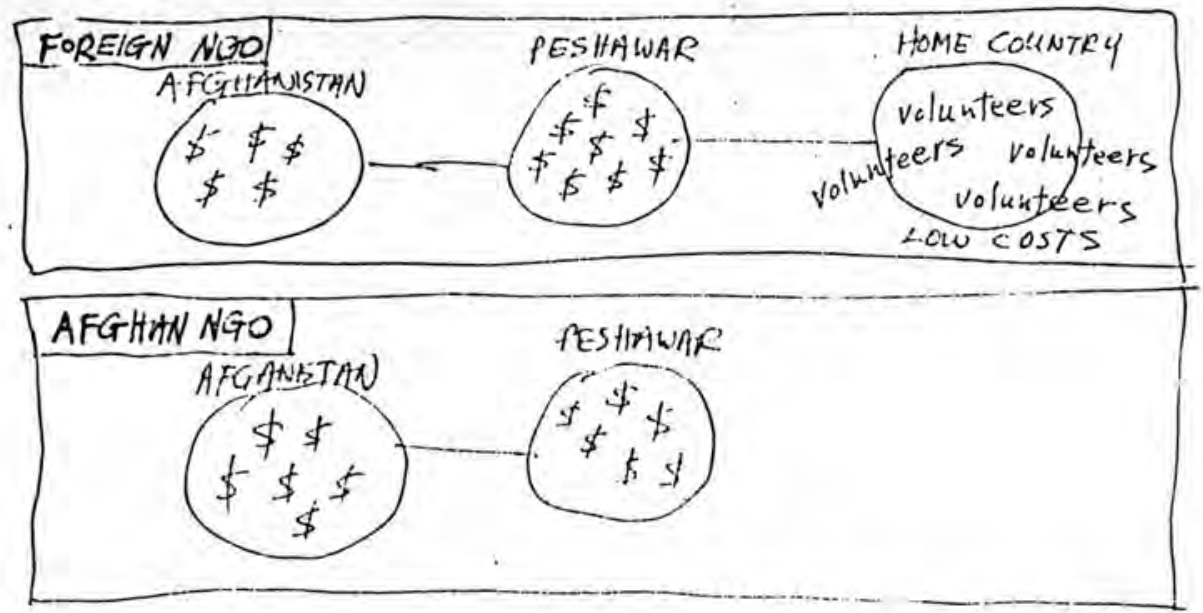

The vast majority of the world's NGOs start and are located in their own community to serve their own people. These are referred to as "community-based NGOs". It usually makes a big difference to the way an NGo runs itself when its own people can see all of it every day.

For example, it is customary in western countries for NGOs to not look richer than the people to whom the NGO is accountable. In the case of the foreign NGOs, this apparently means the people of that nationality. In the home countries, offices tend to be extremely small, there are very few employees and costs are kept very low. The donors simply do not want the NGO to waste money on itself: instead, spend the money on the poorest people who are in need.

However, in Peshawar, Afghans see another kind of behavior with money. The offices of the foreign agencies are in the most expensive part of the city; they have fleets of cars and a high number of employees. Their foreign workers live in the other expensive houses, have their own cars and some have servants. At home the NGOs simply never provide these benefits to employees. (In this author's experience it is even extremely rare that an NGO in its own country owns any cars. Employees use their own cars or use the public transportation system.) If in their own the community, the foreign NGO lived this way, the public would believe that the NGO was operating in self-interest, mistrust it and give it no support at all.

NGOs around the world usually are far more poor than the foreign NGOs in Peshawar. They have no choice but to either have no office at all or when they do, it is at the same level of shelter than the local people have. If it serves a very poor community, the NGO's office is in an equally poor building. They have few, if any, employees and depend mostly on volunteer work. This is reality. As money goes down and down for Afghanistan, it is likely that Afghan NGOs will have no choice but to become more modest operations, based in the communities they serve. Ironically, this could increase Afghan NGOs volunteerism, community participation and accountability: in other words, they will become more like NGos everywhere. To quote an Afghan NGo leader in Peshawar, "For every loss there is a gain. For every gain there is a loss."

The rest of this publication is to prepare Afghan NGOs for these realities. 


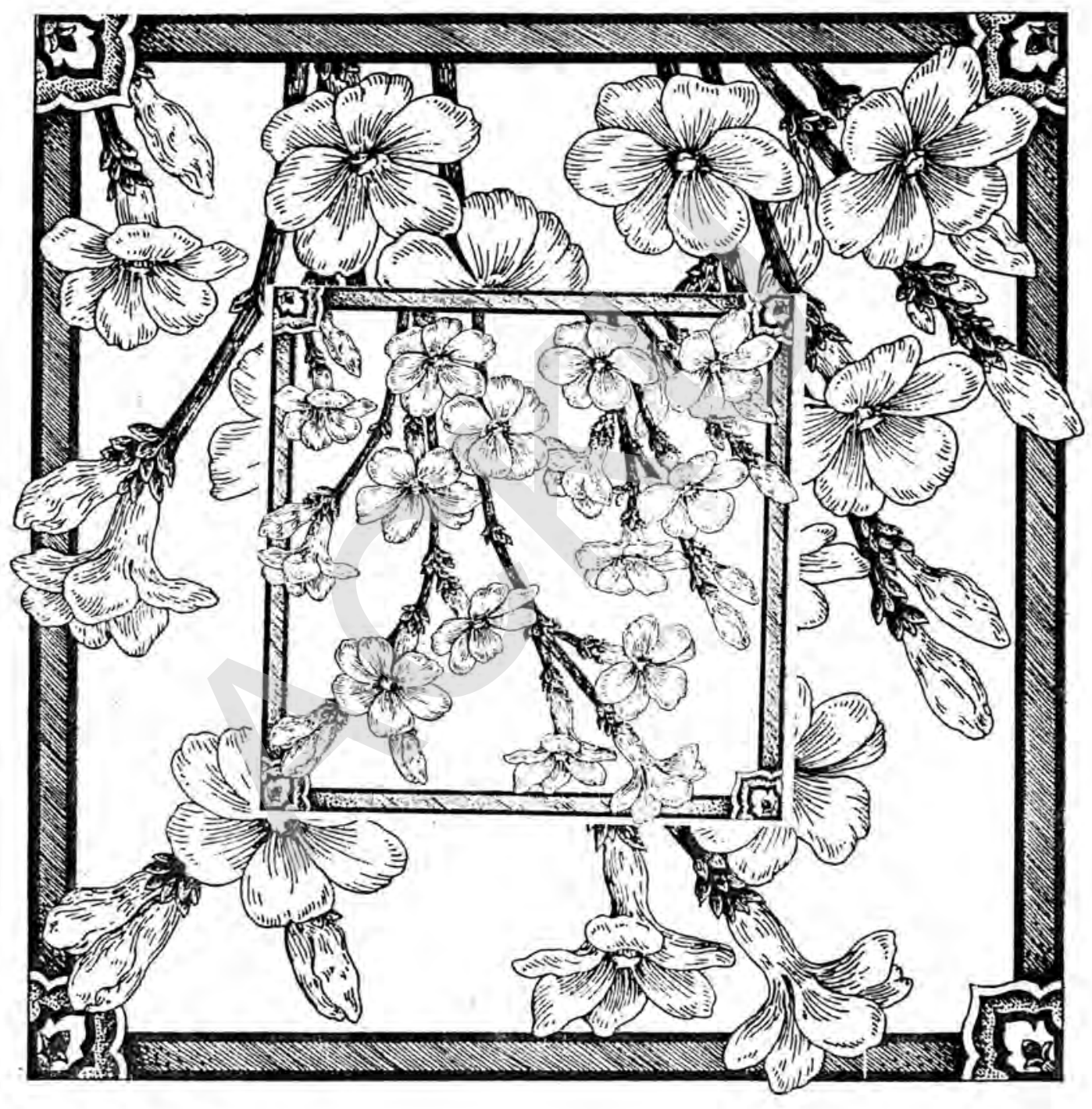


By scope:

-community

-district

-regional

-provincial

-national

-international
By objectives:

$\begin{array}{ll}\text {-religious } & \text {-social work } \\ \text {-education } & \text {-relief and development } \\ \text {-recreation } & \text {-professional development } \\ \text {-the arts } & \text {-environment } \\ \text {-business } & \text {-health } \\ \text {-peace,justice } & \text {-etc. }\end{array}$

A Trip to a Food shop

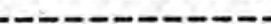

"Why are you so quiet?" my youngest brother asked? "I'm thinking", I answered. "About what?" he wanted to know. Outside our father's house in Canada the snow covered fields spread out to the forest. I'd been looking out the window thinking.

"When I go back to Peshawar I need to teach Afghans about what NGos are. I'm thinking about how to do that. Before the war there were no Afghan NGOs but now they're starting them. I wish I could think of a way to give Afghans a very clear picture of the kinds of NGOs there are and the different things they do. I'm trying to think of really clear ways." I went back to looking out the window. I could tell he wasn't listening again.

The next day my step-mother sent me to buy food. I went to the large supermarket at our nearby village. The food is arranged on high shelves back to back, row after row. There's bright lights, colors and music. I took one of the hundreds of available metal carts on wheels and pushed it around putting into it the things our family needed. Soon I was thinking how almost everything in my country is symbolic of an NGO. So many exist $(100,000$ are registered with government in a population of 25 million. There's one for every 250 Canadians) for every imagineable purpose. Everywhere you go, everything you hear, see, taste, smell, feel or do can be connected to some NGO...

We needed some beef. Packages of red meat were lined up in a refrigerated case. They reminded me of how the farmers who grow beef cattle have many separate NGOs to serve their interests.

They watch world-wide selling of beef, educate the farmers about better ways to breed and grow the cattle and look after the cattle's health. These NGOs of farmers also advise and pressure government on laws that affect the sales of beef; import, export, taxation, etc.

I pushed my cart to section of the shop that sells bread and was reminded that all the kinds of farmers have their own special NGO's. There's individual NGOs for dairy cattle, milk, cheese, 
chickens, pork, fruit and vegetable growers and cereal crops. The farmers who grow wheat have an enormous NGO called the Canadian Wheat Pool. All the farmers sell their wheat into this NGO, it sets the Canadian price and sells it for the farmers. These farmers control their own monopoly.

All the farm communities have many other NGOs. There's even a special one for farm children, called 4-H. It's a national afterschool program which teaches children in fun ways whatever the local main farming is; a boy or girl might be taught anything from growing potatoes to raising a heifer to growing apples or wheat. There's many NGOs for farm women and the family in general. These NGOs do social work such as helping to solve family problems, help the local poor people, increase education for the farm and improve incomes. Every community has several churches and each church usually has a separate NGO which exists for religious reasons. One example is the "Chrisitian Farmers organization". It is farmers who look into chritianity for guidance on how to treat the earth and be responsible citizens.

My father likes tinned fish. At this section in the shop there were hundreds of tins. Picking up one $I$ thought about the fisherman on the east coast of Canada and their NGOs which are trying to solve the problems of fisherman. One of the world's biggest supplies of fish used to be there but now the fish are all gone because the industry took too many out of the water and they were not replaced. There's no other jobs for these people, they have no other way to make an income and families are suffering. Not many years ago other Canadian NGO's concerned with the environment were criticizing the fisherman for taking too many but the fisherman didn't listen. The fisherman and the environmentalists used to be enemies. Now they are friends trying to solve the problems.

A woman pushing a cart ahead of me was wearing a fur coat. I thought she must be either a very brave or very foolish woman because many NGOs exist just to stop the killing of animals for their fur. These NGOs make demonstations outside shops that sell fur coats and often make problems for the people who wear them.

This made me think about the native Canadian Indians who are very badly affected by the NGOs trying to stop fur sales.Traditionally the Indians have lived in the far rural areas and made most of their income by catching the animals for the furs. Indian NGOs work to preserve Indian culture and religion, preserve their land and continue to trap animals.

At the soap section of the supermarket, I thought of artist and designer friends. All the big boxes of soap, like all the packaged products in the shop, were designed and written by professional illustrators, painters, photographers and writers. Some I went to art college with years ago. Now they have their own NGos to promote their work. 
At the milk and cheese section I was delighted to find two old friends from high school. We hadn't seen each other for 15 years. They are on the Board of Directors for the community

association for the mentally disabled. A board meeting was being held that day right across the street and they'd come to get some cheese and fruit to take to the meeting.

When I had all the things on my list, I went to the front of the shop to pay. There beside the cash register and the lady who took my money was a large glass jar. On the jar was a sign asking for money for the local NGo which runs the ice hockey teams. Beside it was a small orange box from an international relief agency asking for money for the famine being repeated now in Africa.

A boy working in the shop put all the things I bought into a heavy brown paper bag. Printed in big red letters on the bag was an advertisement to support local homeless people by giving food to a certain community organization.

As I drove my step-mother's car home so many things kept reminding me of NGOs: even the trees along the road. My father and brothers work in the lumber industry and around our house are the magazines of the national association of lumberman. My step-mother used to be a nurse. She belongs to a retired nurses NGO: which works on nurses pensions and keeping retired nurses informed of new ideas in health care. I belong to a European professional "Association of Project Managers" which helps project managers increase their skills. My sisters are members of NGOs which their children's schools have for parents and teachers. One sister-in-law is a member of an NGO where members do research on family history.

Even the car I was driving was bought with the advice of an NGo. That national NGO exists to test all main kinds of things people buy from soap to tinned fish to cassette players to cars. They test and compare, for example, all the kinds of cars and announce which ones work best, which are likely to last the longest, be the cheapest to operate and which are the worst. My step-mother

had wisely sought this NGo's advice and bought what they recommended. It's a joke in the family that my youngest brother has one of the worst. He ignored this NGOs advice and bought a car only for its good looks. It gives him a lot of trouble. When I arrived home, my brother was there with the hood of the car up as usual, making loud banging sounds with a wrench and cursing.

Canada is only one country with very many NGOs and a long history of having them. The difference they make is so big is can't be measured. They provide services which governments can not possibly provide and many people such as Canadians began deciding a few decades ago they don't want government doing everything for them. They want to help themselves. 


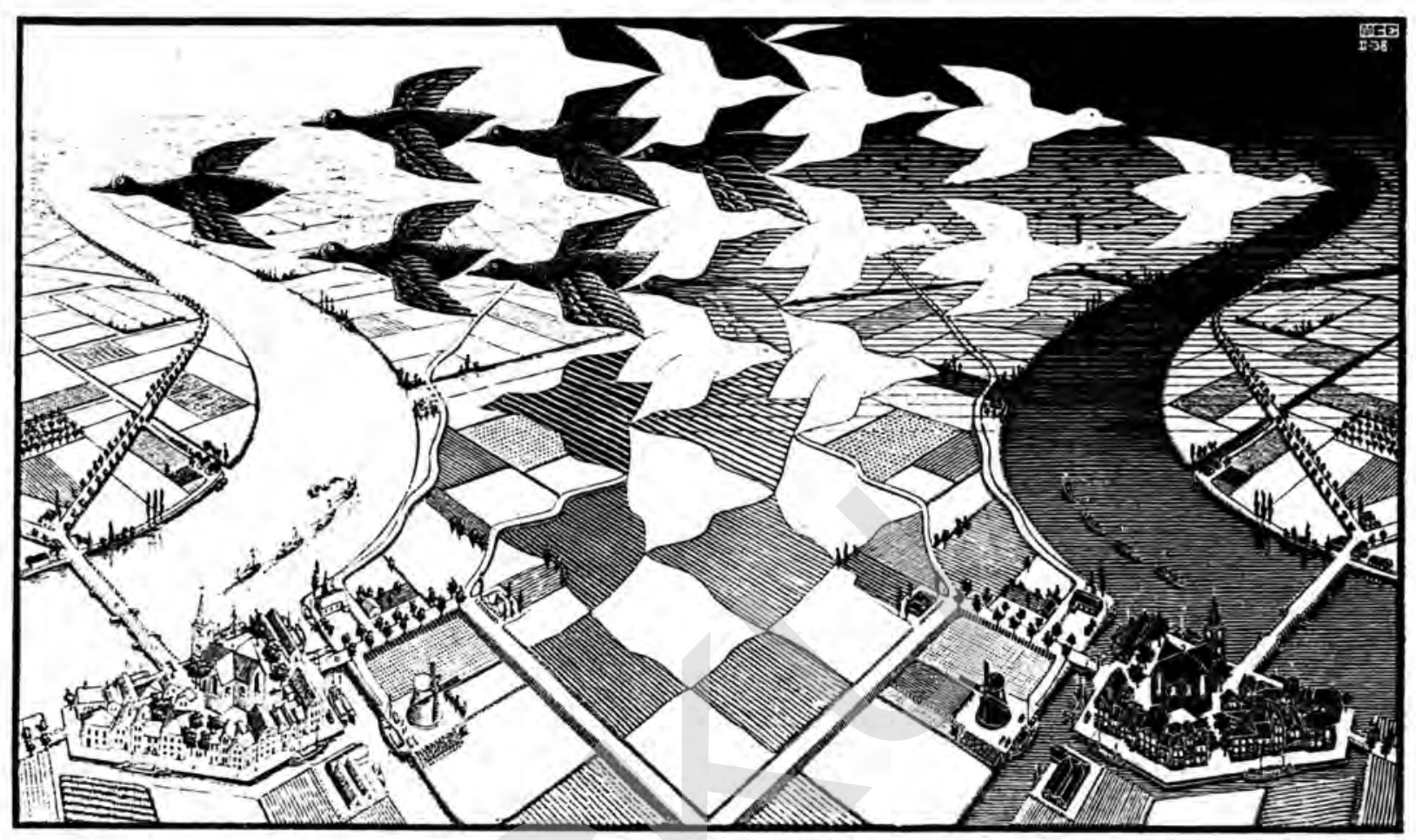

An NGO leader needs to be like a bird. He needs to be on the ground watching and listening to all that is happening. He needs to know as many little details as possible. But a leader especially needs to fly up high above it all, watching far away time and space. What is coming? What is going? What has gone? what is in front of him, behind, beside, under and over. Only with the view of a bird can he know what is best to do on the ground.

:

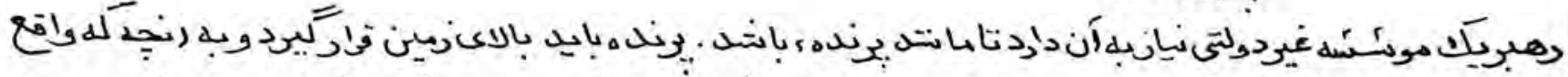

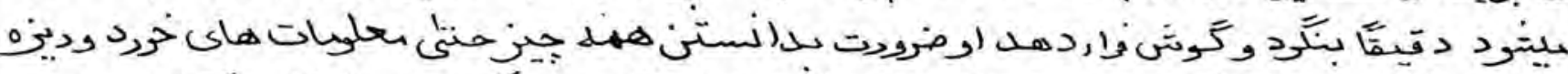

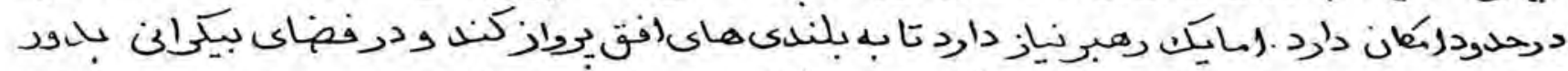

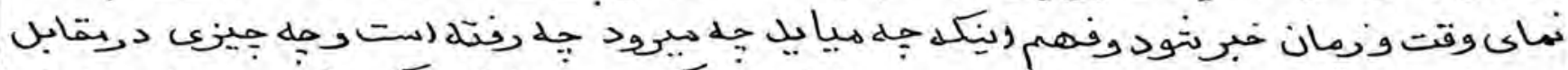

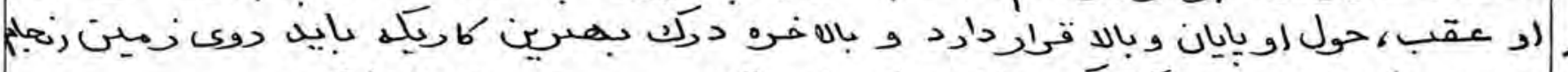

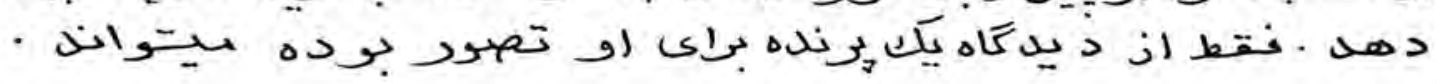


Since the beginning of man, people have had natural ways to organize themselves; into families, clans, tribes, ethnic groups, cultures and communities. Long before governments existed people had ways to solve problems, share what they have in common and work together. Everywhere there have always been natural, locally accepted, understood ways to do such things as solve problems, organize community work, help the poor, support the arts and carry out religious duties. When we look at the meaning of NGOs we find that they are only a revival of these kinds of tradtions: communities looking after themselves.

In Afghanistan communities handled major problems through the jirga. The jirga members were volunteer elders and other respected members of the community. Groups by occupation such as butchers, woodcutters and farmers on irrigated land met voluntarily as needed to solve problems. They chose representatives who handled the situations with outsiders then were answerable (accountable) to their fellow workers. Islamic obligations such as zikat have gone to help the poor and the mosque provides important community services. Former aristocracy and royalty of Afghanistan, like those of Europe and other parts of the world, subsidized artists and scholars to bring beauty and inspiration and wisdom. People have always worked for their communities without pay because they have a sense of duty to the community and everyone benefits from it.

As stable governments evolved in Western countries following the industrial revolution, governments began taking more and more responsiblity from the communities. This was made possible by the taxes they took from the industries. People glady handed to government many of the things they'd done themselves; schools, health care, social work, public works like construction, major agriculture problems, law and order etc. The industrial revolution -the jobs in the factories - drew the population to the cities, breaking down the traditional family and community systems. Government became the main decision maker and problem solver.

Helping the poor in communities was left to churches. They also formed missionary groups that went out all over the world to help the poor as a way of spreading Christianity (these were the first international NGOs). A few rich families organized some of their money separately from their businesses and gave it to the poor. The work of these earliest kinds of charitable "NGos" was their own private affairs. Laws had not yet been made to control them. It was their money so they could do with it whatever they liked. They were accountable to no one.

It took almost 200 years before people started organizing themselves again. Very relevant to the Afghan situation, this change came as a result of two major wars; the second world war and the war in Viet Nam. The wars caused great damage but most importantly they also shook up the way people thought, especially about governments and international relations. 
World War Two brought destruction in Europe and the decline of England as a superpower. Unable to continue as the main colonizer of the world it finally listened to the liberation movements in Africa and Asia and many countries took their independence. The Columbo Plan was then initiated by the newly created United Nations to rebuild and aid the destroyed and freed nations. To handle this enormous work-load hundreds of humanitarian NGos formed.

But what really caused an explosion in the number of NGOs was the era of the 1960s. The vast majority of NGOs in existance today started during or since the sixties. In Europe and North America phenominal change in society occured. The centre point for all was the war occuring in Viet Nam. By then the war's senselessness had become known and was extremely unpopular especially amongst young people. They and some prominent older people were not only speaking louder and louder against it, they were questioning the whole meaning of government and of society and how so many other things had by then gone wrong. Everyone put the blame for the war on the American government but no matter what country people lived in, they became far more suspicious and disatisfied with their own governments. They realized that governments had been left to make all the decsions for far too long and could see the mess governments, often in connection with big business, had made of everything. This was not a leftist movement, it was a rejection of everything. People of all ages from all backgrounds began seeing the trouble they had let happen; culturally, socially, economically, spritually, in the environment, in health and schools, in law and order and justice, in civil rights and so on.

Afghans will remember this period of history in a particular way: crowds of young Western "hippies" passing through Afghanistan. They had long hair and old, poor clothing. But they were fasinated with the traditional ways of Afghanistan, the slower paced, smaller scaled, natural rural and community ways. They loved the clean air, unpolluted by factories and cars and the beauty of the land free of sprawling cities. They hated plastic and synthetic fabrics and anything that symbolized the factories and money of the West. Although hippies are often associated with the bad things of the sixties; drugs and promiscuity, the sixties and the complete reassessment of 1 ife as it was, brought some extremely positive, constructive and permanent change in the West. The hippies were a symbol of people who had lost their culture, tradition and values and were looking for a deeper, more meaningful way of life. In countries such as Afghanistan they found it.

Back home people began doing things for themselves they'd never done before; making their own bread, clothes, furniture and houses, growing their own food. Many people shifted from the cities to the rural areas and began living like their father's fathers. By now the idea of an NGO was widely known and people began forming them in the cities and rural areas. Through forming NGos they were making their own communities and "families". This reason alone may account for such large numbers of NGOs in some countries. Inherited from what the industrial revolution started, most people live in cities away from their families and it is common to not even know your neighbours. For many people, being active in an NGO is a way to have friends, "brothers and sisters" or a community. 
Through forming their own NGOs they began taking back from government control on the decisions that affected their lives. This became the modern idea of "Development" and "Progress" (see Relief and Development, page 25). Hundreds of thousands of NGOs began rushing into existance: like those described in the "Trip to a Food Shop", page 5. Now NGOs cover every conceivable idea, carry out every kind of work imagineable and do things governments simply can not do. And governments kept pace with laws to govern and control the NGOs.

These changes did not only happen in western countries. In all the world NGOs have started. The people of the countries of the South (so-called "developing countries") have only in the last ten to twenty years also begun forming their own NGOs, for very similiar reasons as the Western ones. In the Southern countries they are a new idea. Now on all continents, in countries as far apart as Pakistan, Bolivia, Tanzania, Mexico, Sudan, Lebanon, Thailand, Nigeria, Bangledesh and so on, have their own NGOs to solve their own communities' and countries' problems. Afghans are not alone in their struggles to start and run NGOs. Afghans join a world community of NGOs.

The total effect of so many NGOs in so many countries is $F$ aps that countries now have an organized conscience. People no sel empowered to run their own lives, depending far less on govern. ent. Mistrust of government still exists but when people have their own group power they feel less dominated and controlled. They have also developed techniques for getting what they want from government and how to influence it.

In the West, the relationship between NGOs, government and business has also matured during this time. In many countries now the relationships are strong and respectful. Although governments sometimes try to ignore the opinions of NGOs, they rarely can afford to do so. They don't like to risk upsetting the NGOs volunteers and big bases of support because they are also members of the public who will vote for or against the government in the next election. More and more goverments are depending on NGOs. In most places governments and NGOs find they can not be without each other. They NEED to help each other.

Afghans have never had a period in their history where they could rely heavily on government. By default or choice they have always been their own decision makers and community workers. All NGOs should be doing everything to ensure this continues and not interfere in it or interupt it in any way. NGOs need to be extremely careful not to act like government taking away the responsibility communities have normally taken for themselves. They must stand a little aside and follow what communities decide. They must never impose their ideas, thinking they are superior. As Western people have learned, the very old ways are the new ways.

The NGO must always keep a delicate balance or equalibrium between following and leading. In communities everywhere in the world people sometimes don't understand the exact cause of a problem so the solution they choose often doesn't solve the problem. In this case it is the NGOs role to become the leader: to teach. 
For all the above reasons, Afghans are very highly advised to learn from their own traditional ways, to look again at the goals and dreams of Afghanistan and of jehad. What was jehad about? What Is it about? Humanitarian NGOs can lead ix re-establishing the values, principles and ideals of a religion and culture. (See "In Honor of Jehad; Humanitariansim", page 23). Cultures all around the world have at times foresaken or rejected their goals, beliefs and traditional ways thinking there were better "modern" ways. Later, they realize what they've lost and try to find them again. Sometimes it is too late and all the heritage and things that were DEVELOPED are lost. When people loose the meaning of who they are they loose everything. It is the job of NGOs to not only keep the dreams of a people alive but to make them happen.

Afghan NGOs are coming into existance at a time the Afghan people have no recognized government. It is extremely important that these NGOs organize and operate themselves in ways that will be complimentary to a future suitable government. When the day comes when that kind of government exists, the NGOs and government will find out how much they need each other.

What's the Difference Between Traditional organizing and an NGO?

It's easy to make an NGO sound like a big scientific discovery; something full of mystery and complicated information that only specially educated people can understand. It should not be this way at all.

Some people think of an NGO as a western idea. But look at the definition of an NGO, "voluntary, non-profit and accountable." Look at the definition of management... "plan, control, evaluate". These are exactly what Afghans have within their traditions.

Accountability is not limited to Western tradition. For example; an Afghan father says to his son, "where have you been all day?" The child is required to answer, in other words, be accountable. If the father doesn't like the answer he might punish the child. Suppose a shura makes a deal with an NGO. But only trouble comes. Community members ask the shura, "why did you make a deal with those foolish people from Peshawar?" Islam, more clearly than Christianity, means that all Muslims are accountable to Allah. Muslims know for example, if they buy a Pajero with money meant for orphans, that Allah can have something far more severe waiting for them than United Nations would. 
To explain the difference between traditional and NGOs ways of organizing and managing another analogy helps. It's like the difference between playing a game of volley ball with friends for fun and playing it very seriously with a trained team, by the international rule book, with a referee. The second way, there is a common set of rules and everybody plays by them. If you break the rules the referee will stop you. If you've done something really bad, he'll throw you out!

There is not actually an international rule book for NGOs, instead there are understandings and expectations that have come out of western tradition and custom. Western people think of "NGO ways" as natural ways. (Remember that NGOs came into existance because Western communities had lost their traditional ways to organize and manage themselves.) To learn about NGOs then is to learn more about western culture.

Between Western and other cultures a main difference in the way people organize and manage themselves has to do with literacy and ideas about paper and writing. To a western person things often are not considered real or true until they have been put on paper. It is so deeply ingrained in western culture that people often believe what a newspaper says ahead of a friend. This comes mainly from strict laws forbidding untrue things to be printed.

This cultural difference could help explain some problems Afghans have had sometimes with funders. Many times I've heard Afghans say they visited a funder and he said he'd help. But later they found that he didn't. The trouble is, if he didn't write you a letter or contract, he often does not actually consider it a promise or agreement. (The lesson for Afghans: play the westerners' game: get the promise in writing!)

Traditional, non-literate cultures make agreements verbally. A promise is a promise. With discussion they plan ("how will we distribute the irrigation water?") and evaluate (why did you make a deal with those foolish people from Peshawar?"). And they control to make the things happen. Such traditional leaders know how to listen, when to lead and teach by explaining and convincing. They show their skill and earn their respect in these ways. Wisdom and fairness of leaders gets them far deeper, longer lasting and more effective support than if they demanded respect with weapons or money. For Afghan NGOs, there is a "university" waiting to be discovered in Afghanistan. If everyone listened and watched all the subjects are being "taught" in rural communities. It would be the BEST education for NGOs. What makes a community? If a traditional leader is the "tree" of the community, what are the "roots" of the tree and how do they work? How Do communities make decisions? What makes leaders truly repected? What makes communities truly want to improve their communities? What is the capability of a community? Understanding cultural questions like these is vastly more important to an NGOs work than all the proposals in the world.

No-one can ever assume they know all about their own culture: it takes study, especially when it has been forced through rapid change like Afghanistan. It is very interesting to note that at least two European NGOs in Peshawar employ anthropologists who have several decades of experience in Afghanistan. Their main job is 
to keep observing cultures of Afghanistan to see how they are changing. These then have an effect on how those NGOs approach their work.

This raises the subject of cultural appropriateness of NGOs. Each nationality or culture of NGO must find their own way to work within it's own culture. American ways will not work in Canada. Canadian ways will not work in Sweden. Swedish ways will not work in Mexico. Western ways will not work in Afghanistan. Qandahari ways might not work in Faryab. NGOs need to know both their own ways and outside ways so they they become a bridge between them. only copying foreign NGOs in Peshawar may not only be impossible, in most ways it would be extremely unwise. Where foreigners show little respect for Afghan culture and tradition it is all the more important for Afghans to respect it. If you don't use it, you'Il loose it. (Warning! Warning! Warning! What has been learned from when people loose their culture?) It is up to Afghan NGOs to find the ways, step-by-step.

As far as I can tell the main difference between traditional and NGO organizing is that, like western culture, absolutely everything must be put on paper. An NGO is not in any way a superior or more sophisticated way of organizing or managing than traditional ways. They are only different; by vocabulary and by putting it all on paper. These only make it seem more complicated. The difference also is that NGOs, unlike traditional organizations, usually connect themselves to big outside, international networks. For this there needs to be ways to communicate all the business: writing everything is the way to do it.

This explains NGO's being organized with written rules (constitutions), written plans, collecting data in writing, writing proposals and reports, making written financial statements, making written annual reports, signing written contracts and all the endless other paper work. These document, help communicate and let all those concerned see what has been decided or done. This also explains the heaps of paper foreigners always have around them. 


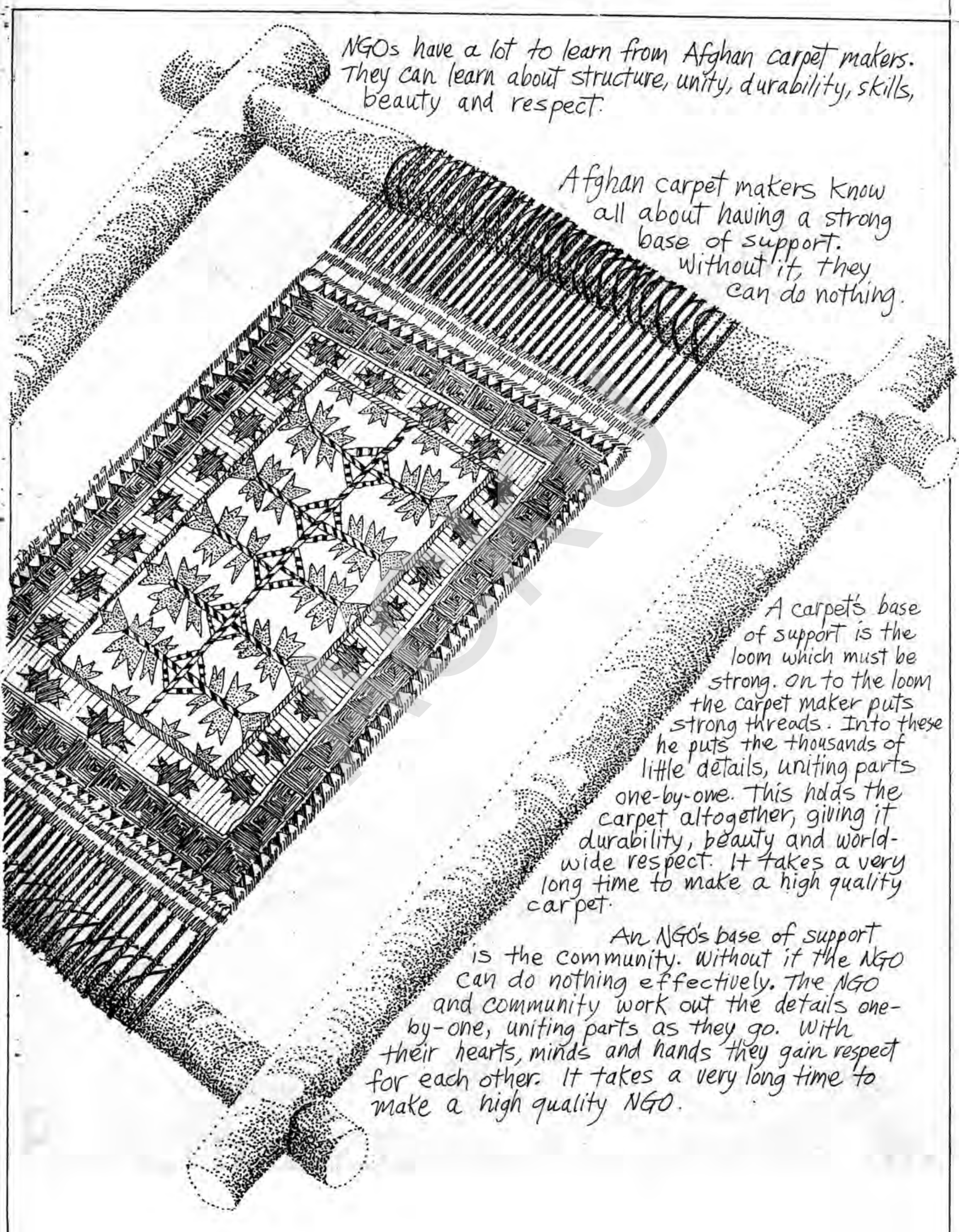




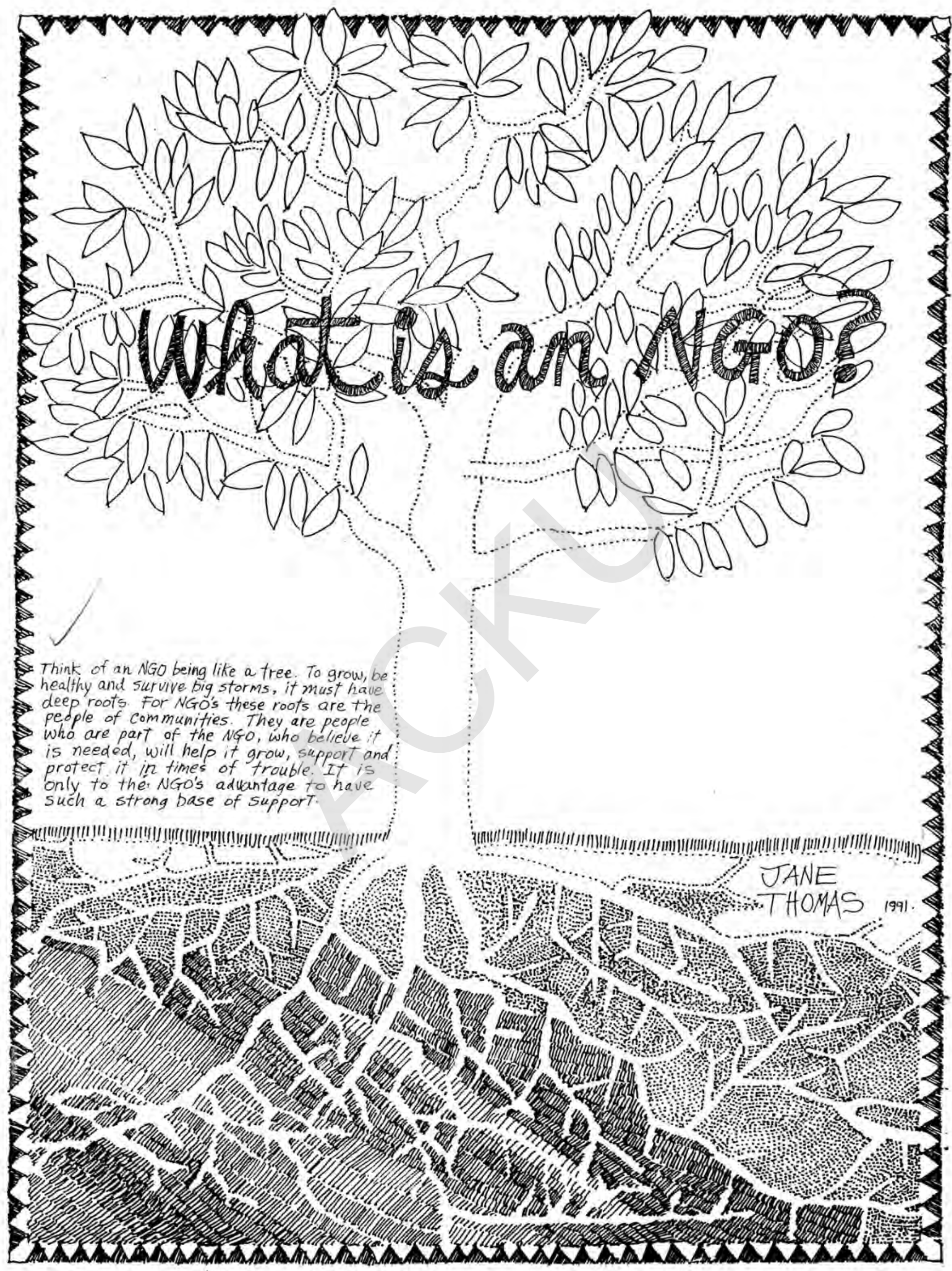


What is an NGO?

It is:

-voluntary

-non-profit

-accountable

-non-political

-a structured organization of people involving a community and official, voluntary, elected leadership (often called a Board of Directors).

A non-government organization (NGO) is different from any other kind of organization. The other main kinds of formal organizations are government and business. What makes an NGO so different and special? NGOs are meant to avoid all the main things known worldwide to cause the biggest problems: money, power and politics.

\section{Voluntary}

1) An NGO, unlike government or business, must depend heavily on volunteerism: people who work for no pay. What money an NGo can raise is meant to go to filling the NGOs objectives, for example helping the poor. People who work for no pay prove they care more about doing good than getting personal benefit. When many people work together for no pay to benefit others they are given a special kind of respect. The volunteer nature of NGOs is what is most special and unique.

This most basic requirement means that an organization which does not rely significantly on volunteers is not really an NGO. It is another job of all NGOs to teach people about volunteerism, its importance and to lead them to volunteer. In a country where NGOs are new, it is another job of the NGO to teach the people what they should and should not expect from an NGO.

2) Voluntary also means the NGO is not something forced or required to exist. NGOs exist because people want them. NGO's also are not obliged, or in certain cases; allowed, to carry out certain activities which are government responsiblities.

Volunteer work of all kinds keeps NGOs and communities self-reliant and independent, free from unsuitable influence by money, no matter what happens to funders. 
Businesses exist to make money and to make a profit. Governments also are allowed to make profit. But an NGO can not exist for the purpose of making money and profit. This does not mean however that NGOs are forbidden to earn a profit. The only restriction is that any profit they make must be put to fill the objectives of the NGO: not put into the pockets of the people in the NGO.

NGOs ideas about money are the main things that determine what the people think of the NGO. If it looks richer than the people it serves, the people believe it is operating in self-interest, therefore is not trusted.

NGOs by their humanitarian work and volunteerism, which keeps costs far lower than government or business, is what gets them respect world wide.

Accountable

The purpose of accountablity is to make NGOs be honest. In other countries, laws force NGOs to be accountable to members, the community, the government and public.

"Accountablity" means the willingness and ability to explain and prove what you (the NGO) are doing or have done. At times it also means explaining why certain things were not done. It only makes sense to be accountable: if you want support to continue, people want to know what you have done with their support so far.

This is what makes a base of support and members so important for an NGO. Knowing that these are the people to whom an NGO is mainly accountable reassures outsiders (funders and other authorities) that they are not alone in checking the NGO. If a community and members clearly support the NGO, this judgement gives the authorities a positive opinion of the NGO.

Each country has specific, minimum legal requirements for the ways NGOs must be accountable. The structure of an NGO is designed to give as many checks and balances as possible to keep it accountable. The main techniques are listed in "Summary of what's needed to be an NGO." In western countries NGOs are required to account for itself publically at least once a year. When an NGO fails to do this government can close the NGO.

However, NGOs in these countries usually go far beyond what government requires. As good management and public relations practices, they provide much more information than is the legal minimum requirement and do so more often and in more ways than government requires. They know that explaining themselves in detail to their publics is mainly to their own advantage. It builds trust. An NGO can not survive without trust, respect and support from the public. 
A very important aspect of NGO accountablity is that they often expect it of each other. They affect each others reputation so much that NGOs normally watch each other. This is an extra kind of insurance that things are being done right.

What do other NGOs of the Southern people think of accountability? One NGO called the Foundation for Community Work was formed in 1974 in South Africa to specialize in pre-school education. In a recent newsletter of the Bernard van Leer Foundation they reported their thoughts...

"We have become accustomed to being accountable to a group that maybe sees itself as superior, doing things on our behalf irrespective of whether we communicated our needs. If we could become empowered as a people, as a community, we would identify our own needs, we would develop the projects we need, or the action plan to meet those needs. Most importantly we would be a ccountable to each other rather than to a force that we cannot really identify with."

Non-Political

Western countries have very strict laws forbidding NGos to have any connection with political parties or political figures. They can not help or represent political parties or figures or take help from them. For disobeying these laws, punishment can be severe: even prison terms for the guilty NGO officials.

In these countries, of course, individuals are free to do what they want in politics. But people who are staff or volunteers for an NGO must always be exceedingly careful not to have their personal political activities mistaken for the political activities of the NGO.

At a certain point, "political" gets extremely hard to define anywhere. In the West, NGOs very often must deal with political officials and opposition parties. It is often necessary to do this to meet the NGOs objectives. Some NGOs feel that it is a humanitarian obligation to $\mathrm{BE}$ political; especially to express opinion publically on government policy which they believe to have a negative effect. But trying to influence politics, holding meetings with figures for discussions of mutual interest and pressuring parties and government to make better policies is quite different than helping increase their power. 


\section{Community}

A community is a set of people who have something in common. They feel interest and some responsiblity toward each other or others.

It can be by geographic location... It might be that they live in the same village. It might be a group of villages...

It could be people with the same ideas or beliefs...the people who go to one mosque...the people who are interested in horses...the people of Sweden who are interested in Afghanistan.

It could be people of the same occupation...the doctors of a province... the engineers of a country...the woodcutters of a valley...the relief agencies serving Afghanistan

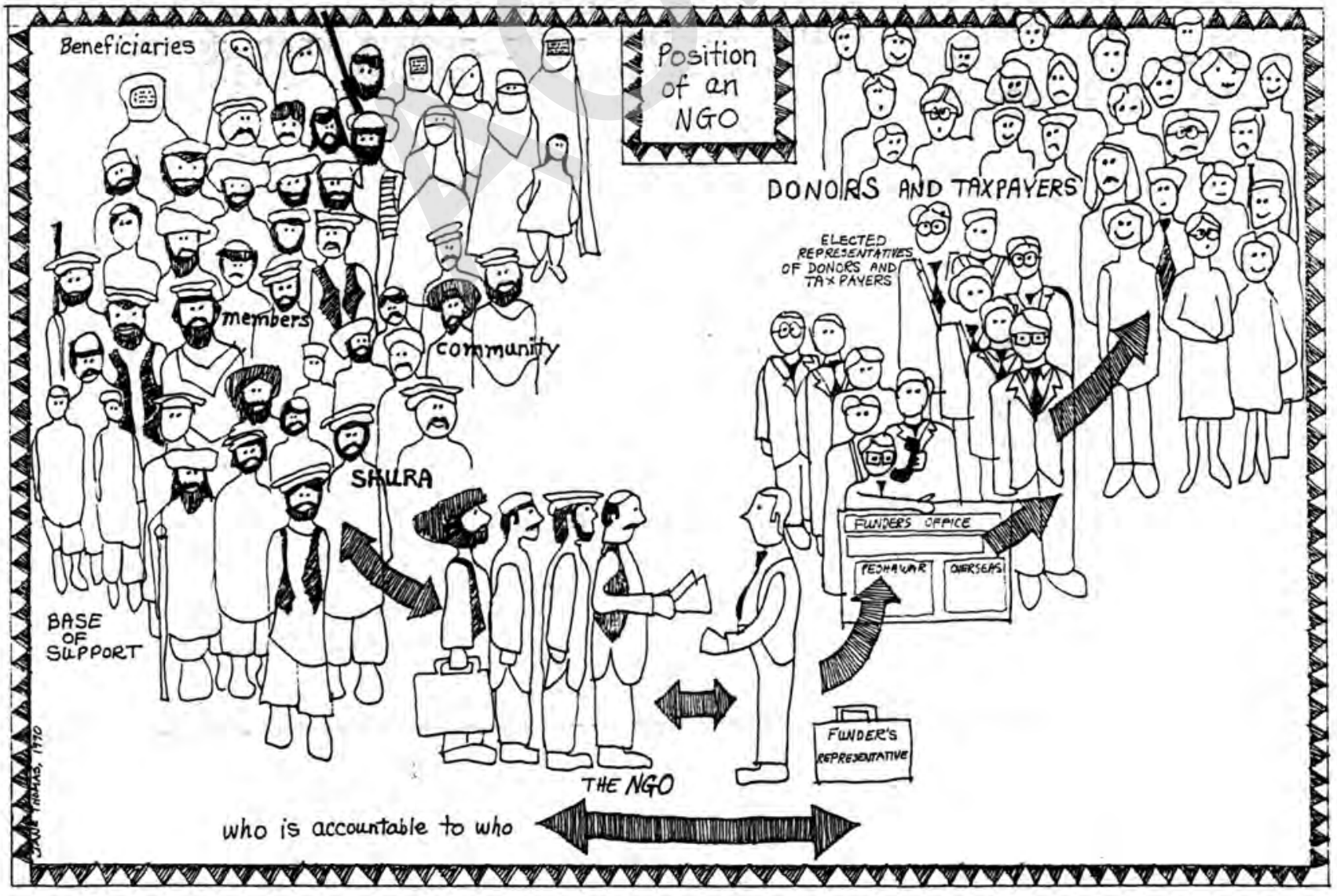


Why are you helping in the re-building of Afghanistan? To you, your answer might be obvious. Each person might have different answers. But, even according to Western, secular experts who train Boards of Directors and NGOs in Northern countries, it is important that an NGO base it's work on the beliefs and values of the people involved.

Reprinted below is an exercise for the leadership of an NGo to do. It is from the "Board/Staff Workbook", published by the Edmonton Social Planning Council, a secular (non-religious) NGO in the city of Edmonton in the far west of Canada. This NGO exists to train Boards, help them solve problems within their NGOs and help Boards and staff work more effectively together. (Illustration from same source, same page.)

\section{EXERCISE for NGO LEADERS 'MEETING}

1. Ask each person to think about and write a list of values, beliefs and insights which they hold as an individual involved in this NGO.

2. Develop a group list on a white board or large sheets of paper. Have each individual contribute their thoughts.

3. Discuss and make the list into a group statement.

4. Use these to then up-date or set the NGO's purpose, goals and plans. Keep referring to these year-round when doing evaluations. Does your work reflect the group's beliefs, values and ideals?
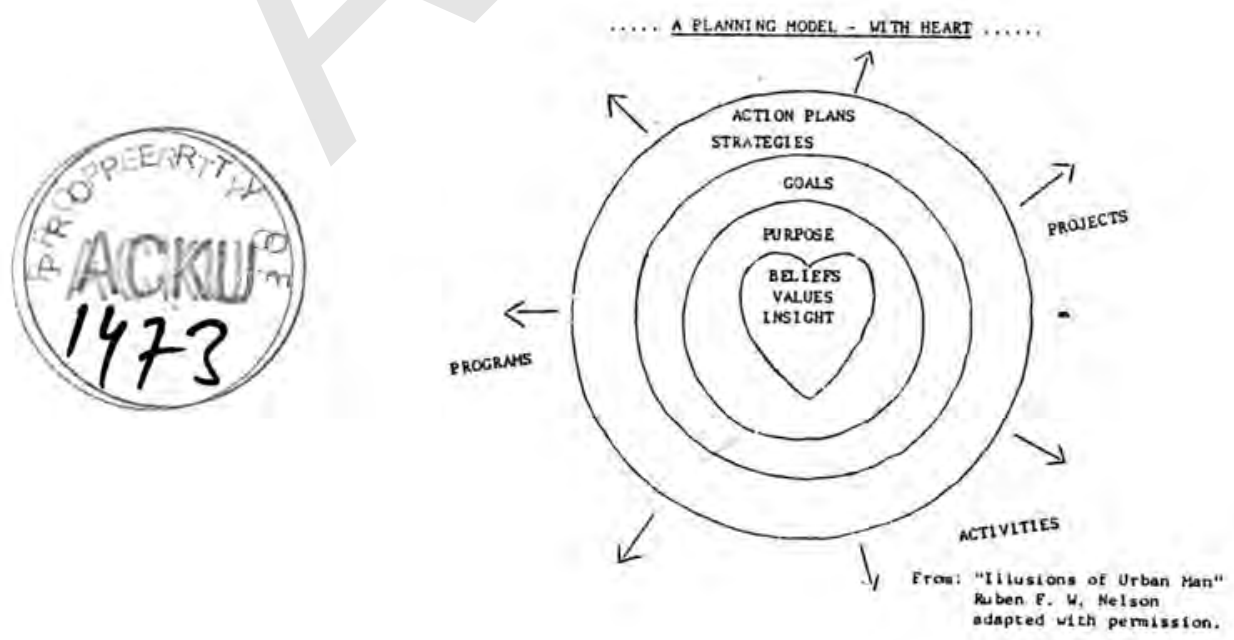
What was or is the purpose of Jehad? To defend Islam? To reestablish Afghanistan on Islamic teaching and ideals? It is wise for Afghan NGOs to look at these questions. While the NGOs have different reasons to exist (health, education, construction, etc.), what are the reasons under the reasons? Is it humanitarianism? If yes, what does this mean and how can it fill the Islamic teaching and keep the dream of Jehad alive?

Humanitarianism means putting values, beliefs, principles and ideals into action. From where do these come? All great religions of the world teach what these are. For Afghan humanitarian agencies, there is no more appropriate place to look than the Holy Qur'an and Hadiths. As Allah's agents on earth; Muslims are to put into practice such values, principles and ideals that are universal:

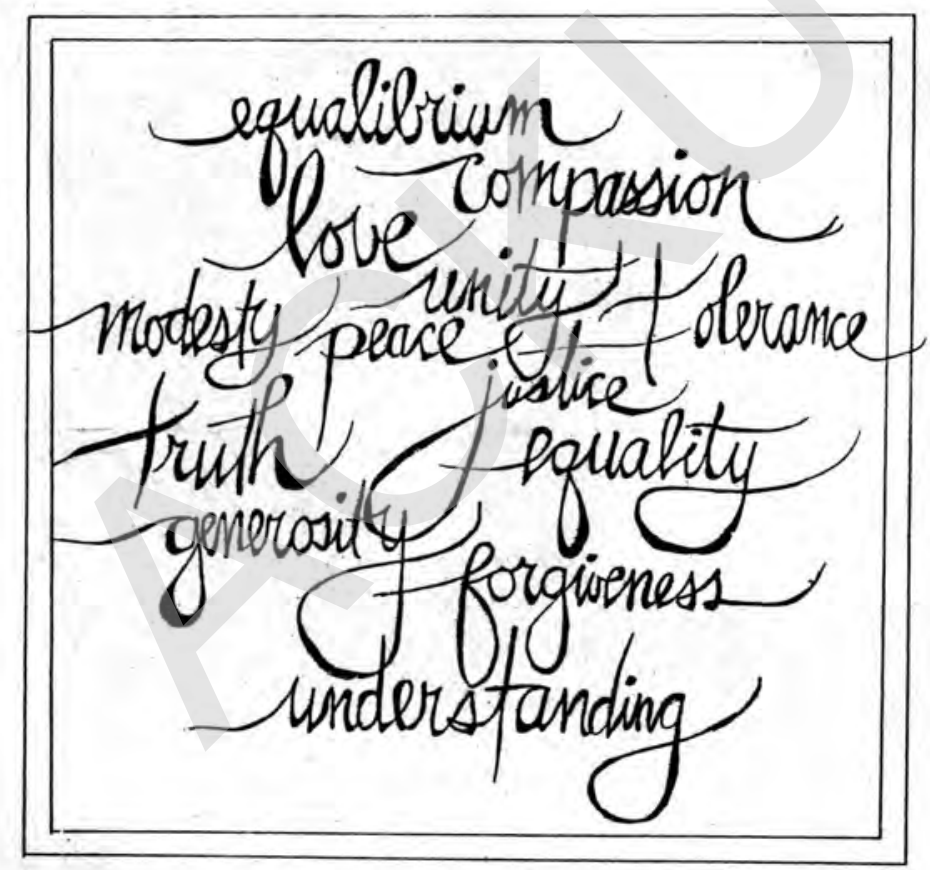

Imagine the difference it could make in Afghanistan if each Afghan humanitarian NGO picked only one of these teachings and for the next five years made it it's strongest priority.

All humanitarian agencies MUST have a clear idea of what they mean by humanitarianism. Their objectives should be based on these kind of teachings and all actions chosen and evaluated

against them. (Will this plan encourage unity?...I don't know if this is true so I will not tell anyone else.... Does this budget show modesty?...I don't like him but I can tolerate him....) 
"Relief" and "Development"

All NGOs need to think about the future and what effect, good or bad, its work could have. When NGOs work to help save lives and improve others, they need to be very clear about what they mean by "humanitarianism" and "relief and development". Only in this way can they know how not to cause problems.

Recently several prominent Afghans were asked about the word "development". Why was it not being used to describe what's needed in Afghanistan? The answer was very clear: the word has been so mis-used in the past and it is associated with so much tragedy that Afghans simply don't want to hear it. It was aid and Taraki's forced "development" schemes that lead to the war.

Thinking of development as the physical things of an "infrastructure", these Afghans said, "but it can't happen anyway until there is peace, unity and money." But several added, "Many Afghans don't want development. Why? Because it means Russian or American and European ideas."

This is a profoundly important analysis. It Is the Afghan experience. Being one of the world's richest countries culturally but poorest countries economically, Afghans have been continually manipulated and exploited by aid and most of the countries of the North were involved. It is already the world's best example of the worst that can happen with aid. It's source takes over the country then bombs and kills the people when they won't take the ideas (communism) that come with the aid. The country made the mistake now known world-wide as the worst mistake a country can make: becoming dependent on outside help, especially when it is from only one source.

After all that Afghans have been through, in 1991 they STILL see the USSR manipulating their country by keeping the Kabul regime in power with aid. Just as understandably, many Afghans are as fearful of the Western influence coming through humanitarian aid agencies via Pakistan. When will Afghanistan be left alone to look after its own affairs? When will it stop being pulled from all directions? When will the conflict stop?

Humanitarian, relief and development agencies have an extremely important role to play. Afghan NGOs perhaps more than any others at this time can make a great difference toward peace. This does not suggest that enemies become friends, only that brothers be brothers. NGOs in all other war situations have found that development and peace come together. It depends tremendously on co-ordination and reduction of competition. When NGOs are coordinated the people around them have fewer reasons for conflict. 
There is a better atmosphere for discussion. There is time and resources to get work done. This is the first major step in the most modern ideas of real developm-it. In 1988, the president of all four hundred canadian relief and development agencies was in El Salvador to see the war and the work of NGOs there. When he came, back he wrote, "If there is genuine development taking place, peace will flourish."

What did he mean by "genuine development"?

In another article in this series on "What is an NGO?", the history of NGOs is described. It talks about rapid change in the 1960s, how and why NGOs began coming into existance in such big numbers everywhere. It mentions how the United, Nations Columbo Plan inspired many international, humanitarian relief and development agencies to form and go to Africa and Asia to help in newly liberated countries. While history in Afghanistan was building toward today's tragedy, lessons were being learned in other parts of the world.

There are thousands, maybe millions of stories to tell about the mistakes made by those international agencies working from the Columbo plan. They, of course, did good but time has told the damage they did. They interferred with cultures. They built dependence. They introduced unworkable technologies. They tried to get the others to act like them. It wasn't only the "beneficiaries" who saw the problems, the agencies themselves finally began admitting it.

By the 1970's many of these agencies began saying, "The way we are trying to help is not helping at all. If we truly want to help how should we do it so it won't cause more problems?" In the two decades since then a whole new field of study has opened: the field of development education. In Europe, USA and Canada now the study of development is becoming very common, in some places as common as architecture, literature and even medicine. People want to know, "what is development for my country and globally?" They study it in new university faculties of "international studies" and can Ph.d's and masters degrees in it. Countless NGOs exist just to teach it (the first time I came to Pakistan was exactly for this purpose: sent to Pakistan by a Canadian, development education exchange program to compare and contrast canada's and Pakistan's development successes and problems. I was sent to learn thing from Pakistan for Canada.) Thousands of NGOs, whether they are in their own country or not try to apply the lessons that have been learned. This is what they have learned...

"Development"

It seems that every countries goal is still economic development but if one main lesson has been learned is that it can only be acheived one very small step at a time. If it goes too fast (Taraki tried it in only a few months), it never works. If it 
forces change on people it never works. If it imposes things on people it never works. If it brings change people don't want it never works. If it is unsuitable to the culture it only does more damage. It cannot come from above because "above" is outside. And people everywhere in the world do not want to be told what to do by outsiders: whether the outsider is from the next village or a country on the other side of the world. Afghans are not at all unique in this way. People everywhere are the same. Even in Canada, so far away in culture and distance from Afghanistan it is the same. The people of my village resent and are suspicious of the provincial capital city. The people of the provincial capital hate the national capital. Everyone wonders, "why have they got planned for us next? Are they going to sell us out? Even for economic development we will not be sold."

Afghanistan is one of many places that's proven how dangerous dependence on outside help is. Even without military invasion great dependence can be done with aid. Military invasions are being replaced around the world by neo-colonialism: ways to dominate and control countries by aid. Aid has a way of capturing people.

Even purely humanitarian aid can be disasterous. In response to the 1985 famine in Africa, huge donations of outside help flooded in from all over the world. A million people died before the help arrived. But another big problem was created. An Ethiopian official said, the trouble was that "the people learned that the solutions for all our problems come from outside. The way the donors supplied the relief assistance taught people to distrust their own abilities and to rely on outsiders for everything." Relief aid (gifts) clearly undermined and delayed genuine sustainable development. The aid did nothing to solve the cause of the famine. Now in 1991, the famine is repeating again and many millions of lives are threatened.

For Afghans: Does the above sound at all familiar? Do you see the dependence of Afghans AGAIN being built on outside help? Isn't it true that it previously was the government of Afghanistan that got dependent: not ordinary people? But now it's ordinary people. Do you see danger signs? How many individuals and communities do you know that are demanding or expecting money from your NGO? How many are waiting until you arrive with the money before they start work they used to do for their own villages themselves for no pay? How many people do you know who will volunteer? Waiting for money means outside dependence has been built.

If Afghans loose their historic sense of self-reliance that could be the greatest damage of the war. What could your NGo do to prevent this problem getting worse?

Afghans could be asking themselves, why haven't the aid lessons learned in other parts of the world (and most certainly what should have been learned from Afghanistan already) been applied here? Why is history being repeated? Afghan NGOs together could play a leading role in making these changes. 
"Relief" or "Welfare"

- Dependence too often is built by relief or welfare kinds of aid. This is any type of assistance given as gifts; food, shelter, clothing, transportation, money, etc. These gifts are sometimes necessary simply to save lives. But in Afghanistan even such help as water wells, schools, irrigation repair, seed supplies and tools are given away as relief gifts, paying the people to do things on their own land. These take away people's initiative to do things for themselves. When the causes of the problems aren't addressed, when able victims won't help themselves, when they are not part of the decision making process and solutions to the problems it is "welfare" or "relief". For decades in both the North and South this kind of help has proven to perpetuate the problems.

Modern Ideas of Development

-Development is a process where people regain the control of the decisions that affect their lives.

-Development is helping people help themselves.

-Development is not just about water, wells and schools. These may be necessary but they alone won't guarantee development.

It depends on more than physical things.

- Development and peace are linked.

-No one can develop anyone else: people and societies develop themselves

-Development treats the causes of problems, not just the symptoms. It is a step-by-step process.

"Give a man a fish and you feed him for one day (relief). Teach him how to fish and he feeds himself for life." (development).

If all the ideas about development can be boiled down into one, it is, "who decides". If these are the modern ideas of development, how can they wait for after peace and unity? They help create it. 
Traditional Relief Thinking*

Victims are helpless and need things that we must provide

We must do a rapid needs assessment

The urgency of needs dictates that speed and efficiency are most important: we cannot afford to take the time consult or involve local people.

Physical and material things are the priorities

The goal is to meet emergency needs and to get things back to normal.
Development Thinking*

"Victims" are active people with abilities and capacities.

A needs AND an abilities assessment is needed

It is never too soon to consider the long-term impacts of outside assistance; from the very

beginning, we must respect the ideas and abilities of local people.

Even if we supply some physical things which people need, we must be sure to rely on and encourage the abilities which people have to handle the problem

The goal is to reduce long-term vulnerabilities and weaknesses and to support the increase of abilities and capacities.

(* from Harvard University, International Development and Relief Project, in collaboration with 50 international NGOs operating in South America, Africa and Asia.)

\section{FOR ALL AFGHANS}

1. What does development mean for Afghanistan?

2. Where does it start?

3. When does it start?

4. Who starts it?

5. How?

6. How would these new ideas about development apply in Afghanistan? How would they effect NGO work? 


\section{NGO ORGANIZING AND FUNDRAISING WHEEL}

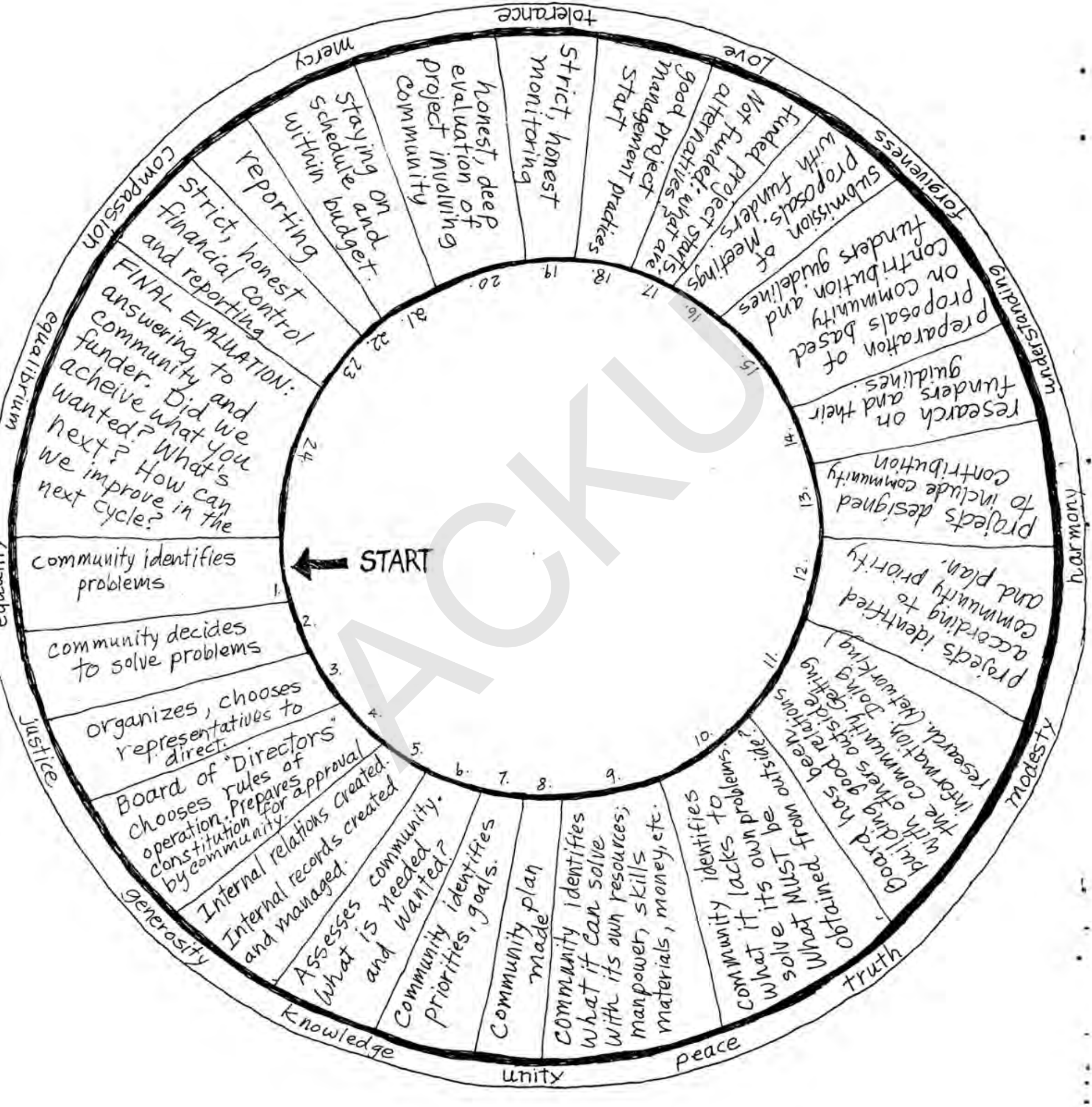

Development based on values, principles and ideals. 
1. A Name. In Western countries the first thing an NGO does to become legally registered is to see if the name they have chosen is like any other NGO"s name. If it is, they are not allowed to use the name. Each name must be distinctive and should be easy to remember. This is already a problem in Peshawar; many names that sound alike. An NGO must always ensure whatever their name is, to always put it exactly the same way each time, not change words around. It should have a name in English and the appropriate Afghan languages. It is also a good idea to have a symbol that is distinctive, especially in a culture where literacy is low.

\section{A structure.}

a) Official, volunteer, elected leadership, often called a Board of Directors. These are the people elected by the members (see below) to run the NGO and be accountable to members. The Board, on behalf of members, is the legal owner of the NGO. As such, the Board takes legal responsiblity for the NGO. They may choose to delegate work to staff members but when something goes wrong, such as a staff member getting in trouble with a funder or members, it is the Board, not only the staff person held responsible. Usually board members are elected from the membership.

The wise head staff person refuses to work alone. For his own protection, he encourages the Board, keeps them informed and involved.

Even in countries where there are extremely high numbers of NGOs, it is not assumed that Board members know how to do their jobs on the board or what is expected of them. It takes training and experience to be a good board member. It is policy of many NGOs to have board training workshops every year.

\section{b) Members}

These are the people most interested in the organization and who take some formal steps to join. These steps need to be in the constitution. Usually it's quite simple, they apply or ask to be members and they are allowed to do so if they agree to the NGO's aims and objectives, agree to abide by the constitution and are accepted for membership by those who are already members. In an NGO there is no advantage to having members who do not truly believe in the NGO. In fact they are usually expected to contribute money and to volunteer. But it is true everywhere that people will not join unless there is something of special interest or benefit to them as well.

Members elect the Board and have other rights and obligations as specified in the constitution. 
c) Volunteers

As already specified, the thing that actually makes an NGO an NGO is volunteers. In community-based NGOs they do all jobs imagineable because there is no money or because the NGO chooses not to spend it when they can get it done for free. Everything from accounting to fundraising, to project design and proposal writing to being project managers to project laborers. Volunteers usually are people who are employed elsewhere so they already have an income. They give their free time to the NGO because they are interested in it. The NGO makes the work fit the volunteer's time available. However, unemployed people also often are volunteers. It helps them increase skills and meet people that might lead them to employment. Volunteers work full time, a day or for only a few hours a week, month or year: however much time they want and can be used by the NGO.

It is never easy to get volunteers. All NGOs must continually promote the idea and treat the volunteers very well. It is very common for Boards to have a special sub-committee just to find volunteers or a paid staff person to do this.

It is an extremely common idea that volunteers time is calculated with a money value put on each hour just as if they were employed. NGOs which keep careful track of this can often use it in fundraising and bargaining for grants to show how much they are contributing to the community or projects for free.

\section{d) base of support, community}

An NGO usually starts in a community and specializes in the needs of only that community. It is only to the NGOs advantage to know the community deeply and to have the community know it. Remember the "story" about the roots of a tree?

An NGO therefore needs to be able to identify specifically the community it represents. And members of that community should be able to identify the NGO. This takes good public relations and communication so that everyone knows each other. It is to no ones advantage to exaggerate the community represented.

An NGO must always be present in the community it serves and to be visible to its base of support. Only in this way can the needed common knowledge grow.

It is known around the world that when communities carry out their own planning or are heavily involved in it, the results are far more successful than if plans are imposed. The wise NGO gets ITS plans from the community.

Almost all communities have other kinds of leaders and representatives such as shuras. An NGO should not interfere with other such authorities, instead, include them. The wise NGO will go to them first and involve them as fully as possible. In some cases, partnerships may be highly advisable. 


\section{e) representativeness}

The NGO's leadership is usually made up entirely of people from the community. Often they choose to include people from outside the community to get their special skills. At the very least in other situations, Boards should include members of the community. No-one can assume they understand the needs of the community especially if they are not part of it. A Board of directors that is comprised mainly of people who are not known to the community are rarely trusted or respected.

\section{f) constitution}

A constitution forms the skeleton of the structure. It is the rules which the Board and members choose to run the NGO. It must be very carefully prepared. (a model constitution and check-list for things to have in a constitution are available from this author. )

\section{ACCOUNTABILITY}

$----------\cdots--$

There are several techniques used. The following are usual mimimum legal requirements, specified in laws of countries...

\section{a) annual general meeting}

NGOs are required at least once a year to call a general meeting of members. At this meeting, the Board reports what has happened that year, the audited financial statement (see below) for the year is presented and the Board election takes place. This is also when rules (byla:s) in the constitution can be changed if the members approve. Only members can vote and approve or disapprove.

\section{b) audited financial statement}

Each year, for the next annual general meeting, members decide who will do the audit for the next annual general meeting. This means that members select people from outside the NGO, volunteer financial experts or a paid company. The job of the outsiders is to go through the financial records of the NGO and make a written summary of all expenses and income. The outsider then makes a presentation at the annual general meeting to show members the statement and explain it. of course, if any profit was made it is shown as well as how it was spent. He gives opinion on the state of finances according to the rules of the NGO and the science of accounting. These outsiders are often very good at making suggestions on how the bookeeping and accounting can be improved.

The NGO and it's bookeeper and accountant should not see this as threatening nor members use it this way. If there is nothing to be hidden, they should proudly co-operate with the outsider who is under assignment by members. 
c) a central monitor and registrar

This role is usually filled by government. The NGO is required to send to them within a short time after the annual general meeting, a list of the Board of Directors, a report from the meeting at which their election took place, a copy of the audited statement and any changes that were made to the constitution. Government people check all the things and if something is wrong, they contact the NGO to tell them to change it.

d) an annual report

In many places a written annual report is a legal requirement. It summarizes the NGOs activities that year and includes a summary of the audited statement. Even where this is not a legal requirement, NGOs do it because it is very useful to provide to donors, funders, the community, other NGOs, etc.

e) fiscal year

This is more of a good management practice than a law. All NGOs need a natural amount of time into which all their business is divided. It can be any 365 day period suitable to the NGo. often NGOs start their fiscal year in the month they began as an NGO. (For example, an NGO starting in November could choose its fiscal year to be November 1 to october 31). All administrative and project costs and income within this period are included in the annual audited statement. The annual general meeting and reporting to government follo: immediately after the end of the fiscal year (example: in this case, December or January.)

f) general accountabilty

Most HGOS go far beyond the above minimum requirements. Many hold monthly meetings of members, produce all kinds of reports, newsletters, etc, and take every opportunity possible to talk with the community. They include the community in planning and evaluating in an on-going basis. This face-to-face contact, no matter where it is in the world, always is more effective anyway.

4. Principles, Values, Beliefs, Ideals

Without these clearly known and practiced an NGo is like a factory, donkey or piece of stone. More than anyone else, an NGO needs to choose these and put them into action.

5. Aims and objectives

An NGO neeris to very carefully choose it's aims and objectives, usually including many pcople in the discussion. These are always included in the constitution, usually in the most prominent part. They need to be taken very seriously and all plans made and evaluations done to see that these aims and objectives are being filled. When an NGO is not meeting its aims and objectives either they should be changed or the NGOs work changed to meet them.

6. Law

NGO's existed before laws to govern them did. Laws grew out of the best and worst things NGOs did. Each country has ways to describe or define the nature, rights, obligations and restrictions of NGCS. All the items mentioned above are the most basic laws and expectations of IjGOs in many countries. 

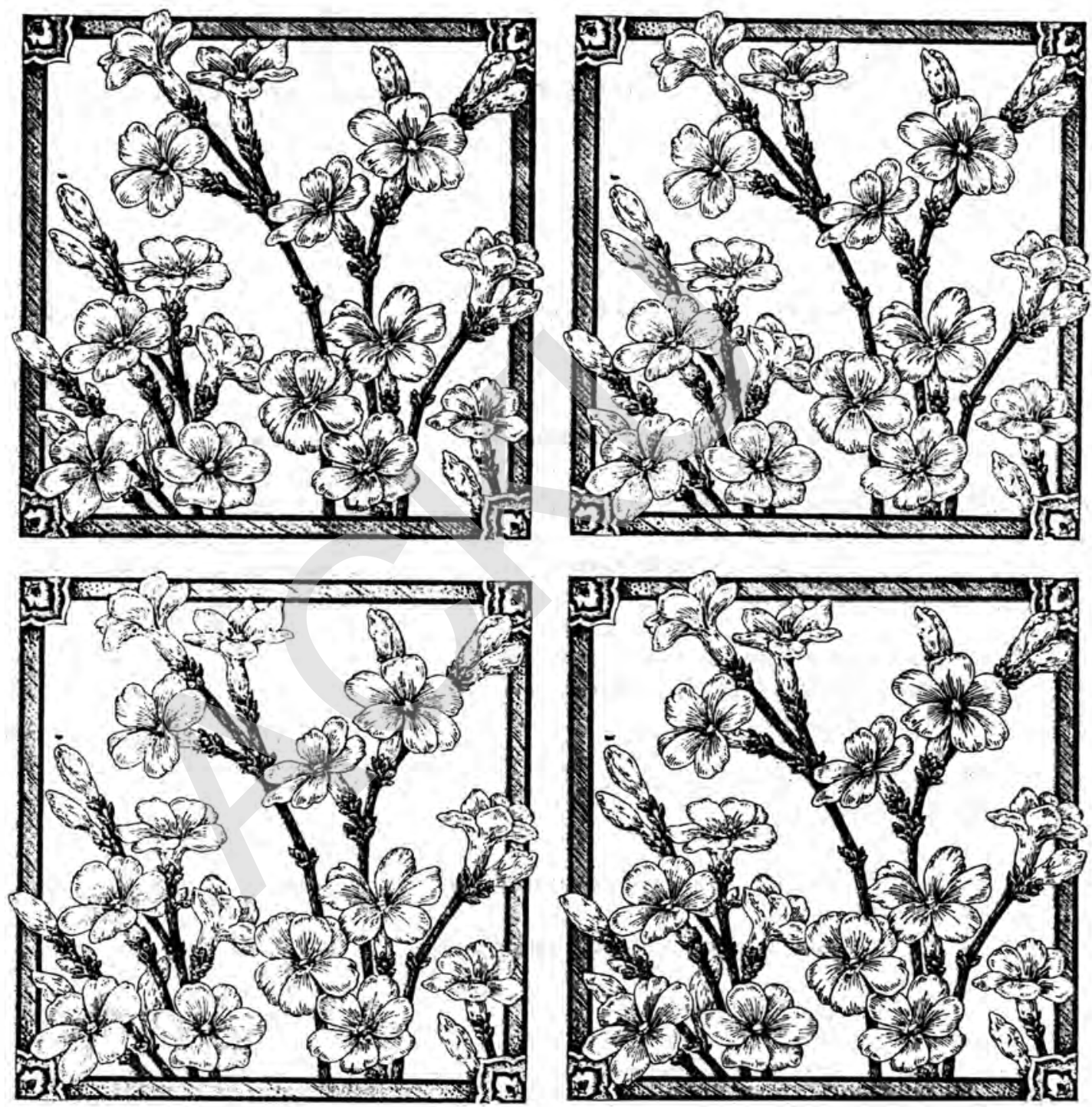
No law or custom exists for Afghan NGOs. It will take many years for these to evolve. Early in 1991 there are already at least 44 groups calling themselves "Afghan NGOs". No one is sure what exactly that means. This is an opportunity to begin making the definition and to clarify what Afghan NGOs could agree to expect from themselves and each other. For this questionaire, please do not worry How the things would be done, only give your opinion if they should or not be features of Afghan NGOs.

What do you think an Afghan NGO should be and do?

1. have a board of directors?

2. should they be elected?

3. should the NGO have members?

4. should NGOs have volunteers?

5. should the NGO represent a community?

6. should the community be represented in the NGO leadership?

7. should the NGO have a constitution?

8. should the NGO be accountable? To whom;

a) suitable government

b) members

c) community

d) funders

9. should the NGO have at least one meeting a year?

10. should the NGO be required to have an annual audited statement? yes no ?
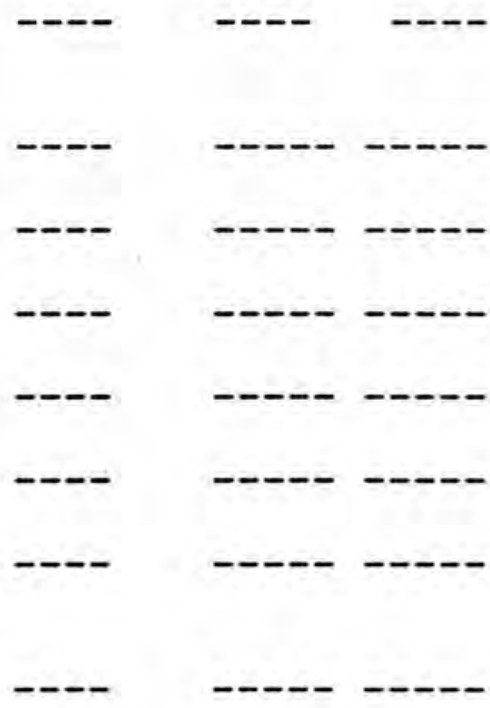
11. should the NGO be required to make a written annual report?

12. should the NGO be expected to have a fiscal year?

13. should the NGO be encouraged to meet with members and the community as often as possible?

14. should the NGO be expected to have a presence in the community full time?

15. should the NGO be based on (Islamic) principles, ideals and values?

(see pg. 23)

16. should individual

Afghan NGOs be self-

determing and independent?

16. should Afghan NGOs have a central registrar now? (To register constituion, receive annual reports, annual audited statements, check names, etc.)

If yes, who should it be?

17. How do you define an "Afghan NGO?" 


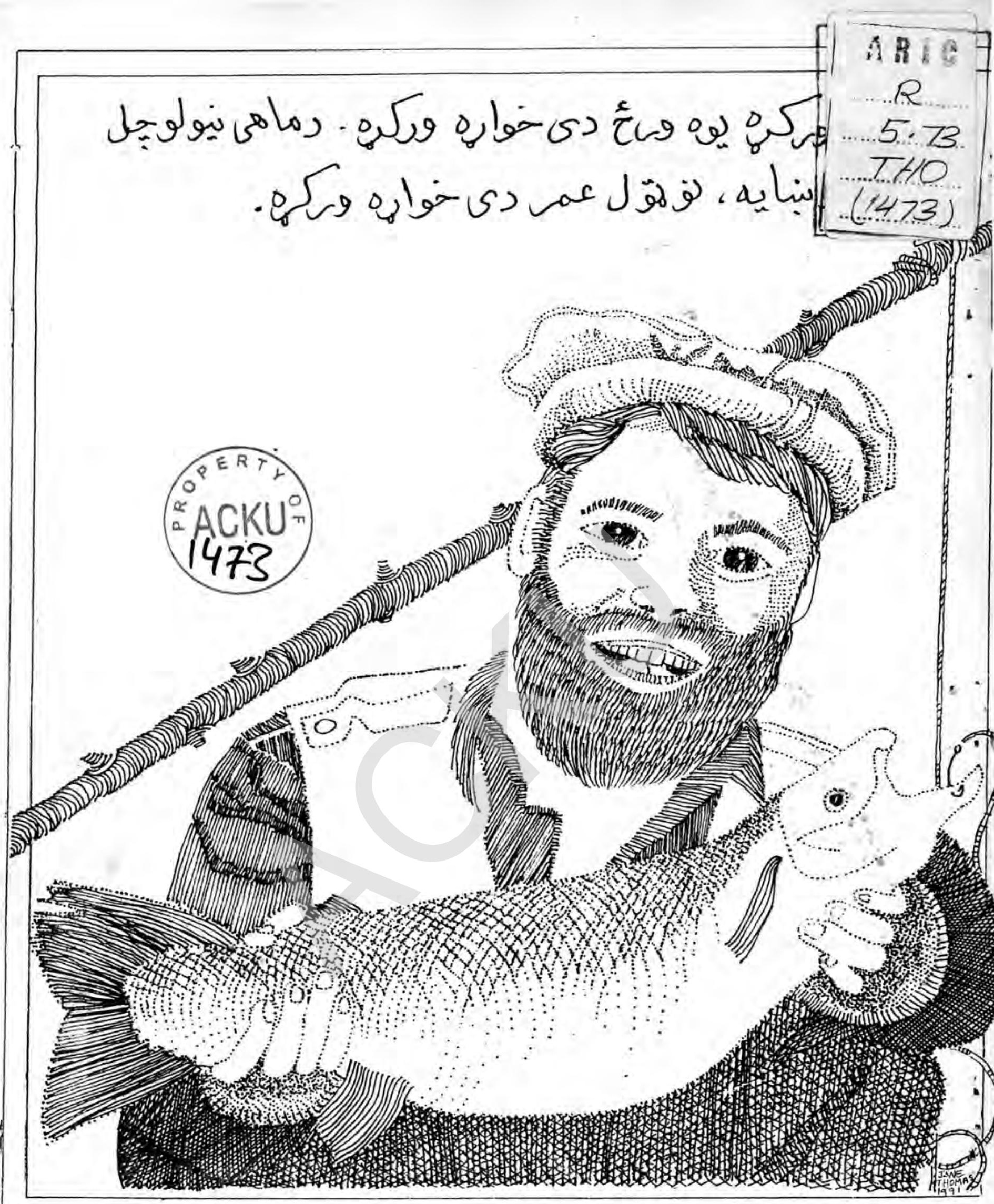

Give a man a fish and you feed him for one day. Teach him how to fish and he's fed for life. 